average of 1200 grammes of distilled water per day. The crackers supplied 43.9 grammes protein, 44.7 grammes fat, and 339 grammes carbohydrates, the total fuel value being 1930 calories. The average daily income and outgo of mineral constituents and nitrogen are shown in the following table:-

Table showing Mineral Depletion_" Cracker" Diet.*

\begin{tabular}{|c|c|c|c|c|c|c|c|c|}
\hline Kind of material. & \multicolumn{2}{|c|}{$\begin{array}{l}\text { Calcium } \\
\text { oxide. }\end{array}$} & \multicolumn{2}{|c|}{$\begin{array}{c}\text { Mag- } \\
\text { nesium } \\
\text { oxide. }\end{array}$} & \multicolumn{2}{|c|}{$\begin{array}{l}\text { Phos- } \\
\text { phorus. }\end{array}$} & \multicolumn{2}{|c|}{ Nitrogen. } \\
\hline $\begin{array}{l}\text { Food per day :- } \\
\text { Bread (crackers) }\end{array}$ & $\begin{array}{l}\text { grm. } \\
0.126\end{array}$ & $\begin{array}{l}\text { gr. } \\
1.94\end{array}$ & $\begin{array}{l}\text { grm. } \\
0.079\end{array}$ & $\begin{array}{c}\mathrm{gr} . \\
1 \cdot 22\end{array}$ & $\begin{array}{l}\text { grm. } \\
0.401\end{array}$ & $\begin{array}{l}\text { gr. } \\
6 \cdot 19\end{array}$ & $\begin{array}{r}\text { grm. } \\
7.02\end{array}$ & $\begin{array}{c}\text { gr. } \\
108 \cdot 32\end{array}$ \\
\hline Distilled water $\quad \ldots$ & - & - & - & - & - & - & - & - \\
\hline Total daily income... & $0 \cdot 126$ & $1 \cdot 94$ & 0.079 & $|1 \cdot 22|$ & 0.401 & $6 \cdot 19$ & $7 \cdot 02$ & $108 \cdot 32$ \\
\hline $\begin{array}{l}\text { Faces:- } \\
\text { Total for three days }\end{array}$ & $3 \cdot 690$ & 56.94 & 0.379 & $5 \cdot 86 \mid$ & $1 \cdot 355$ & $20 \cdot 91$ & - & - \\
\hline Average per day ... & $1 \cdot 230$ & $18 \cdot 98$ & $0 \cdot 126$ & $1 \cdot 94$ & 0.452 & $6 \cdot 97$ & $(0 \cdot 70)$ & $(10 \cdot 80)$ \\
\hline $\begin{array}{l}\text { Urine :- } \\
\text { First day (June 3-4) }\end{array}$ & 0.062 & 0.96 & 0.086 & $1 \cdot 33$ & 0.986 & $15 \cdot 21$ & $10 \cdot 64$ & $164 \cdot 17$ \\
\hline Second day $(, 4-5)$ & $0 \cdot 044$ & $0 \cdot 68$ & 0.095 & $1 \cdot 47$ & 0.622 & $9 \cdot 60$ & $10 \cdot 46$ & $161 \cdot 40$ \\
\hline Third day $(,, 5-6)$ & 0.056 & 0.86 & 0.098 & 1.51 & 0.476 & $7 \cdot 34$ & $9 \cdot 77$ & $150 \cdot 75$ \\
\hline Total for three days & 0.162 & $2 \cdot 50$ & 0.279 & $4 \cdot 40$ & $2 \cdot 084$ & $32 \cdot 16$ & $30 \cdot 87$ & $476 \cdot 32$ \\
\hline Average per day ... & 0.054 & 0.83 & 0.093 & $1 \cdot 44$ & 0.695 & $10 \cdot 72$ & $10 \cdot 29$ & $158 \cdot 77$ \\
\hline Total outgo per day & $1 \cdot 284$ & $19 \cdot 81$ & 0.219 & 3.38 & $1 \cdot 147$ & $17 \cdot 70$ & $10 \cdot 99$ & $169 \cdot 67$ \\
\hline Loss per day $\ldots . .$. & $1 \cdot 158$ & $17 \cdot 87$ & $0 \cdot 140$ & $|2 \cdot 16|$ & 0.746 & $11 \cdot 51$ & $3 \cdot 97$ & $61 \cdot 26$ \\
\hline
\end{tabular}

* Adapted from the monograph Calcium, Magnesium and Phos* Adapted from the monograph Calcium, Magnesium and Phos-
phorus in Food and Nutrition, by Henry C. Sherman, Arthur J. phorus in Food and Nutrition, by Henry C. Sherman, Arthur J. University, New York. Washington, D.C., 1910

As a result of this experiment with the cracker diet the anthors remark: "There was some lack of appetite, and at times a slight feeling of fulness and thirst after meals. There was also in this, as in the second experiment, a slight tendency toward looseness of the bowels." In this experiment it will be noticed that there was a marked daily loss of lime over and above the intake; that the loss of magnesium was out of proportion to the loss of lime; and that the daily loss of phosphorus was nearly double the intake; but the most conspicuous feature relates to the daily loss of nitrogen, over 61 grains. The daily loss of lime amounted to 17.87 grains, while the loss of magnesium was but $2 \cdot 16$ grains; to make the proportions correct according to the intake the daily loss of magnesium should have been $11 \cdot 23$ grains, so that we have reason to believe that there was substitution or replacement, a condition which could take place only as a result of acid excess, the necessary and persistent concomitant of intestinal indigestion. This is the uniform condition in chronic ailments as well as during convalescence from acute diseases, the patient is suffering constantly from lime depletion incident to intestinal indigestion and acid excess due to an unsuitable dietary.

Within recent years an effort has been made to exploit the advantages of organic phosphorus, and we see here the loss is nearly double that of the intake, but the superficial reader must not assume that organic phosphorus is allsufficient. A similar criticism might be offered relating to the excessive output of nitrogen in the form of ammonia through the kidneys, but I have already developed this feature in speaking of the constitutional effects of nitrites in the polluted water. Any attempt to correct this derangement of nitrogen equilibrium, either by the employment of acids (dilute nitro-hydrochloric acid) or by the administration of an alkali, like the spirit of mindererus, would be in keeping with the proposition to employ phosphorus. In either case the benefits would be transient. Along with either line of treatment it would be necessary to administer stimulants, while stimulants would require sudorifics and narcotics, so we see how the vicions circle is completed. On the other hand, by correcting the intestinal indigestion by a suitable dietary, by neutralising acid excess, which is merely a convenient term for indicating a diminished alkalinity of the blood, we should make a favourable start towards convalescence. But convalescence would not be uninterrupted without attention to the magnesium substitution or infiltration which has taken place.

In explanation of the "magnesium theory" and its responsibility for the production of goitre, it should be stated that the magnesium excess finds the organic colloids and combines chemically with them. Now, as the thyroid gland is composed largely of colloid tissue, it is readily seen how easily we can have derangement of function, with irritation and swelling and pulsation and fulness of the throat, along with nervous excitability, when magnesium infiltration has involved the gland. Proof of this is to be found from rational treatment. For example, the average adult dietary contains from $10 \frac{1}{2}$ to 15 grains of lime, while the average magnesium content is about one-half of this. We may assume that acid excess depletes the entire amount of lime, and prescribe an equal quantity. Patients suffering from goitre (recent cases) will promptly respond to this treatment, the nervous symptoms subsiding within a few days after beginning treatment-by administering calcium phosphate, calcium carbonate, or calcium sulphate. An interesting fact should also be mentioned here-namely, that enlargement of the gland begins to subside in about two weeks, just about the period noted by Major McCarrison as the time required to show the bad effects from water containing nitrites. In conclusion, then, there are three cardinal principles to be observed in the treatment of this disease (1) restore the digestive capacity ; (2) neutralise acid excess and (3) promote magnesium dissociation.

I am, Sir, yours faithfully,

Philadelphia, Pa., April 15th, 1913. JOHN AULde, M.D.

\section{ON THE INCIDENCE OF TUBERCULOSIS IN INFANTS AS DETERMINED BY THE VON PIRQUET TEST. \\ To the Editor of THE LANCET.}

Sir,-The von Pirquet test has lately been carried out by us upon 383 consecutive cases admitted to the wards of the Infants' Hospital. The results are shown. as follows : Positive, 4 ; negative, 369 ; doubtful, 10.

The 10 doubtful cases were again tested, when one gave a positive reaction, while the others were definitely negative. The corrected results are, therefore, positive, 5 ; negative, 278 .

From these figures it will be seen that the percentage of infants giving the positive reaction was $1 \cdot 76$.

We are, Sir, yours faithfully,

RalPh Vinchin, M.D. Durh, M.R.C.P. Lond, Senior Physician and Director of the Research Laboratory the Infants' Hospital, London

W. E. Robinson, M.D. Oxon.,

May 5th, 1913. Assistant Physician, the Infants' Hospital, London.

\section{FREUD'S THEORY OF DREAMS.}

\section{To the Editor of THE LANCET.}

SIR,-The interesting lecture by Dr. William Brown on Freud's Theory of Dreams may, I think, give rise to a needless misunderstanding on two or three points.

It is not quite clear what Dr. Brown intends to convey by stating that " as a general rule the memories most commonly aroused are those of the 'dream day' and those of early childhood." He says correctly that "memories of the dream day form part of every dream without exception." That is, they form a part of the "manifest content," which may also embody memories from any period of the dreamer's life. The memories in the latent content may likewise come from any period of life, although Freud is disposed to believe such memories would often not be strong enough to furnish a dream without some reminiscence (phantasy or reality) in the form of a childhood's wish. Too much caution cannot be taken to avoid confusing the latent with the manifest content of the dream. Freud writes: "It is quite incredible with what stubbornness readers and critics exclude this consideration and leave unheeded the fundamental differentiation between the manifest and the latent dream content."

Dr. Brown himself does not seem quite free from this "stubbornness." His hunting dream is, of course, the manifest content, and Dr. Brown seems satisfied to apply the fear felt in the dream to the hunt. Analysis might record some latent content having nothing to do with hunting and would perhaps show Dr. Brown that he no more fears hunting in 
dreams than he does awake. The recurrence of the feeling will perhaps suggest to him that there is a meaning (other than fear in the hunt) behind the manifest content which is worth his analysing out. From the passage on p. 1183 it might be inferred that Dr. Jung uses his word-association test in analysing dreams. This would be an error. He employs what Dr. Brown calls the " more natural method" (although anything less " natural" than psychoanalysis $I$ do not know). In fact, Dr. Jung now ravely, if ever, employs word-association in psycho-analysis.

Lastly, may I ask Dr. Brown which followers of Freud maintain that "the wishes forming the dream thoughts or latent content of dreams are always of a sexual nature." There are one or two persons who have separated themselves from Freud to whom this might apply, but it is hardly fair to call them "followers" of Freud unless it is literally meant that they come after Freud. Freud himself writes "that there are many dreams satisfying other than-in the widest sense-erotic needs, as dreams of hunger, thirst, convenience, \&c.'

Dr. Jung and the Zürich school would allow a large number of dreams whose latent content betrays no sexual character. If I may be allowed to call myself a follower of Freud, I have published some dream analyses from my patients of a non-sexual character. It must be, however, remembered that in Freud's hypothesis there are impressions received in childhood which never reach consciousness. These impressions are not so much repressed as hindered from entering consciousness. It is these wishes thus checked that Freud regards as the real inciter of the dream. There is so much tentative in the theories underlying psychoanalysis, and there are so many pitfalls for us merely medical workers, that I would like to express my delight at having reasoned criticism from so distinguished a psychologist as Dr. Brown and one so sympathetic to this work.

I am, Sir, yours faithfully

Welbeck-street, W., April 28th, 1913.

M. D. EDER

\section{TREATMENT OF TYPHOID FEVER BY TINCTURE OF IODINE.}

To the Editor of THE LANCET.

SIR,-In THE LANCET of April 5th you note an article in the Journal de Médecine et de Chirurgie Pratiques upon the Treatment of Enteric Fever by Tincture of Iodine. You state that " although the therapeutic use of iodine in that disease was suggested so far back as 1859, and reference has been directed to the matter since, notably by Dr. David Walsh in 1907, no extensive trial seems to have been made of this method." Dr. G. Perez, in the above-mentioned journal, urges that the time has arrived to put this method to an extensive practical test. Perhaps I may be allowed to make a few remarks on this subject.

My experiences of enteric fever came in the early days of practice, and the results of the simple treatment in question amounted to a revelation. A mixture of equal parts of tincture of iodine and of pure carbolic acid was prescribed, with directions for two or three drops of the mixture to be added to a tumblerful of water, which was to stand constantly by the patient's bedside, to be renewed as required and to be taken freely by the patient. Under this treatment, in every case so far as I now remember, the tongue cleaned rapidly, the temperature fell steadily, diarrhcea ceased-in a word, the fever was cut short and robbed of its dangers, and normal convalescence ensued. I had many opportunities at one time of seeing enteric fever treated in this way as well as by the ordinary expectant and symptomatic plan, and the comparison was all in favour of the iodine method.

My interest in enteric fever was maintained in later years as a dermatologist, for it seemed to me that in the enteric rash we had a suggestive picture of the etiology of a large group of symptomatic eruptions. The bacillus typhosus has been found in the " rose spots," showing, from my point of view, a probable attempt on the part of the body to throw off a generalised infection by the skin channe] a process described by me in other words as that of "excretory irritation." Further, irritation of alternative excretory outlets in enteric fever not infrequently sets up such inflammations of renal and respiratory channels of excretion. On purely losical grounds, applying the general law of ircitation of excretory outlets to the particular case of scarlet fever I suggested in 1897 ("Excretory Irritation," p. 37), that it was desirable to disinfect the urine as well as the other excreta in that complaint. For some years past I understand that course has been adopted in the Metropolitan Fever Hospitals. A similar suggestion was extended to the urine of enteric fever patients.

As you remark, "treatment based on bacteriological observations has of recent years attracted so much attention that the employment of drugs has not been fully investigated." That species of neglect certainly seems to have overshadowed the iodine treatment of enteric fever. Had this method been applied in the South African war, I have little doubt that many valuable lives would have been saved in our camps.

It always seemed to me possible or probable that the good effects were in all probability due to the iodising of the blood serum. It is not clear how the iodine could exercise a direct effect upon the intestinal ulcers, unless, indeed, it were first absorbed from the stomach and excreted later into the intestine. Then, again, it is interesting to speculate how far the therapeutic result would be attributable to the mere fact of supplying the patient with drinking water in which the ordinary bacteria were no longer in a living state, but reached the stomach charged with various endogenous thera peutic potentialities. However, these and other interesting problems, possibly of much practical importance, would naturally occur to any scientific investigator who might take up the matter.

I am, Sir, yours faithfully

Harley-street, W., April 26th, 1913. DAVID WALSH.

\section{INTRAVENOUS INJECTIONS OF IODOFORI IN PULMONARY TUBERCULOSIS.}

\section{To the Editor of THE LANCET.}

SIR, - WVill you kindlv permit me to refer to some points in the report in THE LANCET of May 3rd on the discussion at the meeting of the Royal Academy of Medicine in Ireland on the use of iodoform in pulmonary tuberculosis.

Dr. J. B. Coleman condemns the intramuscular iodoform. benzoyl-chloride treatment. He may be right. I have no experience of it. But I must protest against that method being confused with the one $I$ laid before the profession in 1903 and have advocated since. I is iodoform in ether alone. The introduction of "benzoylchloride" has completely altered this treatment, and any inferences to be drawn from it. My method is useless unless the iodoform is introduced intravenously. As Dr. W. G. Smith pointed out, a powerful and "extremel irritating compound" with independent actions of its ow has been added, and these require single and separate investigation, otherwise there will be confusion. $\mathrm{Dr}$. Coleman then went on to point out the low germicidal. action of iodoform, and inferentially, therefore, its inutility. If so, why is it still so extensively used all over the world? Surely the profession cannot all be mistaken in their belief in its value. He also stated that dry powdered iodoform may contain living germs. So may dry boracic acid and dry corrosive sublimate wool, and so I understand may most high germicides in the dry state unless sterilised and hermetically sealed. But there is no comparison between dry iodoform and iodoform in solution in ether. Dry powdered iodoform is a very stable body, an ethereal solution of it is extremely unstable, decomposing rapidly, and liberating free iodine under the influence of light in the presence of oxygen or moisture. Freshly dissolved it is pale straw coloured. If this is exposed to direct sunlight it becomes as dark as the liniment of iodine in a few minutes. Continuing, Dr. Coleman emphasised the toxic properties of iodoform, giving the names of a number of distinguished medical men to support his statement. But in the report of his paper no account was given of the mode of application, the quantities used, or the duration of treatment before toxic spm. ptoms supervened. These I maintain are necessary. Because toxic symptoms can follow the use of arsenic, strychnine, or morphia, are they to be generally condemned? Finally, he asserted that "in pulmonary tuberculosis the intravenous injection of iodoform was attended with special dangers "which he enumerated. Does Dr. Coleman make this assertion after a prolonged personal experience of the intravenous injection of an ethereal solution of iodoform, or is it supposititious? There are probably few 